\title{
The Investigation and Analysis of Basketball Class Teaching of Beijing Pin WANG ${ }^{1, a,{ }^{*}}$ \\ ${ }^{1}$ College of Physical Education and Sport, Beijing Normal University, Beijing China \\ apinzi@mail.bnu.edu.cn \\ ${ }^{*}$ Corresponding author
}

Key words: Beijing, vocational colleges, Basketball teaching

\begin{abstract}
This paper uses data analysis method, interviewing method and questionnaire method to survey and analyze the teaching content and evaluation of basketball classes in Beijing higher vocational colleges. The results show that the basketball classes' teaching time is not enough, and basketball teachers have a gender imbalance and a younger trend, meanwhile, the teachers' professional titles are generally lower, a majority of teachers have bachelor degree while a minority have college degree, The basketball teaching material and syllabus are always the same as the average regular college courses'.
\end{abstract}

\section{The Research Objects and Methods}

Over these years, basketball class in the sports teaching in higher vocational schools has been in a dominant position, but due to the influence of the traditional sports teaching mode, the basketball class in teaching content and evaluation is still in the limitation of physical education major teaching category. Meanwhile, the students are lack of the knowledge of basketball and the conception of basketball experience in depth, at last, students will have just learned a few basic actions without knowing about the connotation of basketball. Therefore, the research of teaching content and evaluation methods in higher vocational colleges and universities' basketball classes is of great significance both in carrying out the thought of "health first" and the improving of students' quality.

\section{The research Objects}

The research objects are basketball class in vocational colleges in Beijing (except students majoring in PE or military and police), and the respondents of the survey are the teachers and students in 10 vocational colleges in Beijing. (management institute of science and technology Beijing, Beijing industrial vocational and technical college, Beijing vocational college of electronic science and technology, Beijing institute of information technology, Beijing institute of technology of profession of north of Beijing, Beijing economic and trade vocational college, Beijing institute of economic management professional, Beijing vocational college of politics and law, Beijing finance \&trade vocational college, Beijing traffic vocational and technical college)

\section{The research Methods}

The Method of Documentary consulting materials by searching the websites such as Chinese journal net(CNKI), China academic web sites, and referring to our country sports academic periodicals during 2000-2009 that involve higher vocational colleges and ordinary colleges and universities sports teaching and evaluation methods of the reform of journals and academic papers to understand the research situation.

Questionnaire According to the purpose of the paper and the need of the research, following the basic requirements of the questionnaire designing after consulting experts and repeatedly revised, 
we designed the questionnaire for teachers and questionnaire for students ". There are 10 higher vocational colleges in Beijing, and we gave out three questionnaires to teachers and 48 questionnaires to students 38 for male and 10 for female). The issuance of questionnaires and recycling situation (see Table 1).

Table 1 issue and recycling questionnaire

\begin{tabular}{ccccc}
\hline $\begin{array}{c}\text { The } \\
\text { questionnaire }\end{array}$ & $\begin{array}{c}\text { Distribute } \\
\text { copies }\end{array}$ & $\begin{array}{c}\text { The recycling } \\
\text { number }\end{array}$ & $\begin{array}{c}\text { Valid } \\
\text { questionnaires }\end{array}$ & $\begin{array}{c}\text { Effective } \\
\text { recovery }(\%)\end{array}$ \\
\hline The teacher & 30 & 27 & 25 & 83.3 \\
The student & 480 & 455 & 387 & 80.6 \\
\hline
\end{tabular}

Mathematical Statistics On the basis of effective data gained by the survey, we used SPSS12.0 and Excel2003 to analyze the data in a scientific way, ensuring the research is objective and scientific.

\section{The results and analysis}

\section{The Present Situation of Course in Higher Vocational Colleges of Beijing}

In the outline that the former state education commission put forward in 1992, the teaching structure of physical education in common universities should be: basic classes for grade 1, option classes for grade 2, and elective courses and health sports courses for grade 3 (see Table 2).

Table 2 the ordinary university sports curriculum evaluation index system of guidelines

\begin{tabular}{ll}
\hline \multicolumn{1}{c}{ indicators } & \multicolumn{1}{c}{ Evaluation connotation } \\
\hline $\begin{array}{l}\text { Fixed } \\
\text { number of }\end{array}$ & $\begin{array}{l}\text { First and second grade must be offered physical education, while the third } \\
\text { grade should be provided elective course. Class hours are } 2 \text { hours a week, }\end{array}$ \\
$\begin{array}{l}\text { year of the } \\
\text { course }\end{array}$ & $\begin{array}{l}\text { totally } 18 \text { weeks, , and } 72 \text { hours the whole academic year } \\
\text { The type of }\end{array}$ \\
According to the goal of the college sports and the rule of sports discipline \\
itself, targeted to open base, options, taking the course in, health care, sports \\
option class, category, to meet student needs
\end{tabular}

the results can be seen as (Table 3), there are no colleges open classes fewer than two semesters. 1 college for three semesters, taking $10 \%$ of all the colleges in survey, nine colleges for four semesters, taking $90 \%$, and no college open classes more than 4 semesters.

Table 3 basketball class statistics course situation $\quad(\mathrm{N}=10)$

\begin{tabular}{cccccc}
\hline Classes of & 1 the term & 2 the term & 3 the term & 4 the term & $\begin{array}{c}\text { More than } 4 \\
\text { semester }\end{array}$ \\
\hline $\begin{array}{c}\text { School } \\
\text { number }\end{array}$ & 0 & 0 & 1 & 9 & 0 \\
\hline
\end{tabular}

The results show that the open rate of basketball courses of Beijing vocational college is $100 \% .9$ of 10 higher vocational colleges school open four semesters of basketball class, 1 opens three semesters of basketball class, Basically they ensures the teaching requirements of 2 hours per week, and totally 18 weeks of each term, and 72 hours the whole academic year. The theory course of basketball takes 0-4 hours and practice part takes about 56-64 hours, while 2-4 times minus for bad 
weather and 2-3 times for exam, so the practice class part can only have 50-58 hours a year. Therefore, in the limited time, students are difficult to grasp the basic theory and tactics of basketball, which has a great side effect for the students to set up the lifelong sports consciousness. By investigating into the basketball class, the main reasons for the course lessens are: first, a student needs to intern for a year, second, due to the enrollment expansion of vocational colleges in recent years, the field and basketball teachers are in short, third, the leadership in vocational colleges do not value the basketball class, so they open more specialized courses.

\section{Beijing basketball teachers in higher vocational colleges}

Basketball teachers are the concrete executors and organizers. basketball teachers' age structure refers to the number of faculty members of all ages on the proportion of relations, to some extent, it shows the comprehensive strength and creativity. students acquire basketball knowledge and skills by imitating the teacher's behavior in many cases, so to enlarge the number of basketball teachers, and make a balance of sex and age structure is of great significance. Through the investigation on basketball teachers in 10 vocational colleges, the results of the survey is in the Table 4.

Table 4 Teachers' gender, age, statistical $\quad(\mathrm{N}=25)$

\begin{tabular}{|c|c|c|c|c|c|c|c|c|}
\hline \multirow[t]{2}{*}{ age } & \multicolumn{2}{|c|}{24 to 30 years old } & \multicolumn{2}{|c|}{31 to 40 years old } & \multicolumn{2}{|c|}{41 to 50 years old } & \multicolumn{2}{|c|}{$\begin{array}{c}50 \text { years of age } \\
\text { or older }\end{array}$} \\
\hline & \multicolumn{2}{|c|}{ The number of $\%$} & \multicolumn{2}{|c|}{ The number of $\%$} & \multicolumn{2}{|c|}{ The number of $\%$} & \multicolumn{2}{|c|}{ The number of $\%$} \\
\hline male & 7 & 28 & 11 & 44 & 3 & 12 & 1 & 4 \\
\hline female & 2 & 8 & 1 & 4 & 0 & 0 & 0 & 0 \\
\hline
\end{tabular}

As can be seen from the Table 4, in the basketball teachers of vocational colleges in Beijing, young teachers are of majority, and the proportion reached $84 \%$, male teachers takes $88 \%$ of the total number of teachers, while female teachers takes only $12 \%$, the ratio is $7: 1$, which is not harmonious. Seen from the results of the investigation and analysis, the vocational college basketball teachers in Beijing are gradually completing the alternation in age. The reasons are: due to the enrollment expansion of vocational colleges in recent years, some old teacher have retired, in order to finish the chec, the higher vocational colleges have to make the number of basketball teachers increased, so a group of graduated students enrich the basketball teachers group.

\section{Beijing Vocational college Basketball Syllabus and Teaching Material}

The syllabus and teaching material is the specific construction form of the teaching content, which is to serve the basketball teaching [6]. Formulating a complete syllabus and selecting teaching materials conform to the teaching reform is the guarantee of teaching content and evaluation method.

Table 5 the syllabus and teaching statistics $\quad(\mathrm{N}=10)$

\begin{tabular}{ccccc}
\hline & The syllabus & The syllabus & $\begin{array}{c}\text { The teaching } \\
\text { material }\end{array}$ & $\begin{array}{c}\text { The teaching } \\
\text { material }\end{array}$ \\
\hline & posses & without & posses & without \\
\hline The school & 10 & 0 & 7 & 3 \\
The percentage (\%) & 100 & 0 & 70 & 30 \\
\hline
\end{tabular}


According to statistics in the Table 5, all of the basketball teaching courses in higher vocational colleges in Beijing have syllabus. Learned from the field visits, we know that the syllabus of vocational colleges mainly imitate the ordinary universities'. Yet due to the sports teaching environment, teachers are difficult to teach according to the syllabus. from the view of teaching material usage, $70 \%$ of colleges have teaching materials, while $30 \%$ haven't, which reflects the randomness in basketball class teaching, and, it is difficult to guarantee the systemic and rigour of teaching content and evaluation methods.

\section{Conclusions and Suggestions}

Beijing vocational college basketball teaching hours, less teachers' sex ratio imbalance, showed a trend of getting younger over as a whole. Beijing vocational college basketball teaching material and teaching syllabus used ordinary undergraduate course colleges and universities basketball teaching outline, teaching situation is worrying.

Leadership of higher vocational colleges should pay attention to the basketball teaching in the place, funds, teachers and teaching hours, which is to ensure a better development of physical education. To strengthen the construction of basketball lesson teaching staff, improve the structure of the basketball class teachers, teachers' education through various channels to improve basketball level, and reasonable increase basketball teaching hours.

\section{Reference}

[1] Liu Cheng Yong. Exploration of higher vocational college basketball elective course teaching, Journal of Mongolia sports technology, 2008, pp. 107-108.

[2] Wu Zhencheng Li Benyuan. Mainly talks about the basketball option class teaching in higher vocational colleges, Journal of private science and technology, 2009, pp. 62.

[3] Chen Gongli. Investigate and analyze the present situation of sports teaching in higher vocational colleges in Anhui province, Journal of Anhui sports science and technology, 2009, pp. 87-89.

[4] Li Jingjian. Girls basketball course in higher vocational colleges experimental study [J]. Science and technology education, 2009, pp. 213.

[5] Liu Fujun. Sports teaching reform in higher vocational colleges. Journal of professional science and technology, 2009, pp. 4-5.

[6] Ceng Xianzhi. The problems existing in the sports teaching in higher vocational college and countermeasures. Journal of liaoning vocational college, 2009, pp. 49. 